DOI: https://doi.org/10.18371/fp.2(34).2019.183575

УДК 336.71:330.131.7

\title{
ТЕОРЕТИЧНІ ЗАСАДИ ВИЗНАЧЕННЯ СУТНОСТІ СИСТЕМНО ВАЖЛИВИХ БАНКІВ
}

\author{
ЛИТВИНЕНКО Олеся Володимирівна \\ аспірант, ДВНЗ «Університет банківської справи» \\ ORCID ID: http://orcid.org/0000-0002-2891-7625 \\ e-mail: olesia.lytvynenko@gmail.com
}

Анотація. У статті визначено різні підходи науковиів до тлумачення понять «системно важливий фінансовий інститут» та «системно важливий банк». Виявлено різниияю між поняттями "системно важливий фінансовий інститут», "системно значущий фінансовий інститут» та "системоутворюючий фінансовий інститут. Автором розглянуто поняття системного ризику та системної важливості банку. Подано авторське трактування поняття «системно важливий банк» з урахуванням розкриття його основних характеристик.

Ключеві слова: системно важливий фiнансовий інститут, системно важсливий банк, системний ризик, системна важливicmb.

Постановка проблеми. В фінансовій системі будь-якої країни можна виділити групу найбільших фінансових інститутів, що мають вплив не тільки на фінансову систему, а й на економіку країни загалом. Такі установи зосереджують значні обсяги капіталу, активів та зобов'язань, характеризуються високим ступенем фінансової взаємозалежності. В багатьох випадках поширення диспропорцій та збільшення системних ризиків спричинені результатом діяльності саме системно важливих банків, а пробле-
Аннотация. $B$ cmaтье определены различные подходы ученых к толкованию понятий «системно значимый финансовый институт» и «системно значимый банк». Выявлены различия между понятиями «системно важный финансовый институт», «системно значимый финансовылй институт» и «системообразуюший финансовыи институт. Автором рассмотрено понятие системного риска и системной важности банка. В работе представлена авторская трактовка понятия «системно значимый банк» с учетом раскрытия его основных характеристик.

Ключевые слова: системно значимыцй финансовый институт, системно значимый банк, системный риск, системная важHocmb.

ми, 3 якими зіткнулися деякі великі банківські інститути, стають небезпекою для всієї банківської системи. Відсутність усталених критеріїв до дефініції «системно важливий банк» та посилення їх впливу на фінансову систему України в умовах несприятливого економічного та політичного середовища, викликає необхідність поглиблення теоретичних досліджень, особливо в контексті розвитку понятійного апарату діяльності системно важливих банків. 
Аналіз останніх досліджень і публікацій. Із часу розгортання кризи посилився інтерес науковців до питання системно важливих фінансових інститутів, внаслідок чого з'явилась значна кількість наукових публікацій, присвячених цій тематиці. Окремим теоретичним засадам функціонування системно важливих банків присвячені праці провідних зарубіжних (А. Альошина, Т. Андріан, В. Ачарія, М. Бруннермаєр, Е. Сучкова, М. Таштамиров, Я. Январ) та вітчизняних (В. Лавренюк, І. Краснова, Н. Приказюк, М. Стегнієнко, Н. Шульга) науковців.

Незважаючи на те, що вивченню особливостей діяльності таких установ присвячено значну кількість праць зарубіжних та українських науковців, варто відзначити, що залишається низка питань, які потребують детального дослідження, зокрема в аспекті формування теоретичної бази системно важливих банків.

Мета статті полягає в узагальненні теоретичних підходів до трактування сутності системно важливих банків, визначенні характерних ознак системної важливості та окресленні власного бачення понятійного апарату діяльності таких установ.

Виклад основного матеріалу. В світовій банківській практиці протягом багатьох років існувало переконання, що великі фінансові установи $€$ найбільш стійкими елементами фінансової системи і їх банкрутство неможливе. Основна думка була зосереджена на тому, що ці фінансові установи володіють найбільш диференційованим портфелем активів, мають високу ступінь фінансової стабільності, що дозволяє забезпечувати достатній за- пас стійкості та мінімізувати вплив руйнівних факторів зовнішнього та внутрішнього середовища [1, С.179]. Внаслідок транснаціоналізації банківської діяльності та міжнародної фінансової консолідації кількість таких фінансових установ стрімко зростала [2, C.44].

Варто зазначити, що проблема системно важливих фінансових інститутів була порушена ще в 1984 році американським конгломератом С. МакКінні, який вперше ввів розмовний термін «too big to fail» (занадто великий, щоб збанкрутувати»). Першим великим банком, що отримав такий статус був Continental Illinois [3, C.16]. Як зазначають І. Краснова та В. Лавренюк «на той час це питання не набуло сучасної гостроти, проте посприяло фундаментальним зрушенням у плані наукового дослідження місця та ролі системно важливих банків» [4, С.18].

В науковій літературі використовують різні поняття для визначення фінансових установ, що відіграють ключову роль у забезпеченні стійкості всієї фінансової системи. Серед таких понять найчастіше зустрічаються наступні: «системно важливі фінансові інститути», «системно значущі фінансові інститути», «системоутворюючі фінансові інститути. При цьому під фінансовими інститутами можуть розуміти різні фінансові організації (банки, банківські групи, страхові компаніï), а також інфраструктурні організації фінансового ринку (платіжні системи, центральні контрагенти тощо). Проте найчастіше поняття системно важливих фінансових інститутів відносять саме до банків. Поняття «системно важливий банк» $\epsilon$ вужчим та 
похідним від поняття «системно важливий фінансовий інститут».

Варто зазначити, що термін «системно важливий фінансовий інститут» («systemically important financial institution») був вперше використаний у 2006 р. у звіті Європейського центрального банку про стабільність фінансових ринків, тоді як введення поняття «системно важливий банк» відбулося після кризи 2008-2009 рр. [5]. Отже, можна говорити, що термін «системно важливий банк» є похідним від «системно важливого фінансового інституту» та в подальшому ці поняття розглядатимуться у комплексному підході.

Виходячи з міжнародних підходів у загальному системно важливими фінансовими інститутами називають найбільші фінансові установи, що мають великий вплив на функціонування всієї фінансової системи.

Термін «системно значимий фінансовий інститут» вживається переважно російськими вченими та зустрічається здебільшого в російськомовній літературі. Так, Е. Сучкова під системно значимим фінансовим інститутом розуміє установу, яка має значний вплив на всю фінансову систему [6, C. 54].

На основі проведеного аналізу можна зробити висновок, що поняття «системно важливий фінансовий інститут» та «системно значимий фінансовий інститут» $є$ подібними за сутністю, мають однакові характерні ознаки, а особливості їх вживання пов’язані із специфікою перекладу.

Деякі вчені для характеристики фінансових інститутів, що мають великий вплив на фінансову систему, використовують поняття «системо утво- рюючі фінансові інститути». На нашу думку, цей термін не є коректним для визначення фінансово важливих фінансових інститутів. Етимологія терміну «системно утворюючий фінансовий інститут» вказує на ключову роль такої установи, їі обов'язковий характер для існування системи як такої. Відповідно до цього банкрутство таких установ $є$ неможливим, оскільки будучи основою системи, неодмінно призведе до їі краху.

На підставі аналізу і порівняння різних термінів, що характеризують фінансові установи, які здатні мати істотний вплив на фінансову систему, можна дійти висновку, що вчені часто ототожнюють поняття «системно важливий фінансовий інститут», «системно значимий фінансовий інститут» та «системо утворюючий фінансовий інститут». На нашу думку, таке ототожнення $€$ некоректним, оскільки ці поняття мають принципово різні значенНЯ.

Проаналізувавши визначення різних авторів, можна сказати, що дискусії про сутність системно важливих банків виходять 3 трьох напрямків: їх здатності впливати на фінансову систему, відповідності комплексу ознак системної важливості та синтезу здатності впливати на фінансову систему та наявністю ознак системної важливості. Варто відзначити, що визначення сутності таких установ завжди відбувається з урахуванням системного ризику.

Згідно з першим підходом системно важливі банки розглядають через їх здатність впливати на фінансову систему. Тобто такі банки розглядаються через призму їх системної важливості, 
при чому остання визначається наслідками діяльності таких банків.

Як зазначає аналітик Deutsche Bank Research К. Вайстроффер «якщо розглядати системно важливі фінансові інститути, то з одного боку, - це установи, недостатнє регулювання яких може викликати масштабну та затяжну кризу, а з іншого боку, - це установи, діяльність яких має вирішальне значення для нормального функціонування фінансової системи та реального сектору економіки в розрізі створення суспільного блага» [7, С.3]. Тобто діяльність системно важливих банків може мати як негативний (при ïх банкрутстві), так i позитивний вплив (при нормальному функціонуванні такі установи виступають певним «фундаментом» для забезпечення фінансової безпеки всієї системи).

Варто зазначити, що більшість вчених акцентує увагу саме на негативному впливі на систему у разі банкрутства системно важливого банку чи порушення його діяльності. Так, Я. Анвар під системно важливим банком розуміє банк, банкрутство чи його проблемний стан якого можуть спричинити фінансову кризу при прямій дії або слугувати спусковим механізмом для поширення шоків [8, С.1].

Важко не погодитись із думкою А. Альошиної, яка вказує на те, що визначення системно важливих фінансових інститутів дозволяє виявити так звані «сегменти напруги» на фінансовому ринку, внаслідок чого можна запобігти породженню фінансової кризи [9, С.34]. На думку вченої, такі установи є осередками потенційного ризику для фінансового сектору, тому вони мають бути об’єктами постійного нагляду з боку регулятора.

Отже, ситуація на фінансовому ринку значною мірою залежить від стану системно важливих банків, тобто такі установи обов'язково відповідають ознаці здатності впливати на систему. При цьому, на нашу думку, їх стабільне функціонування забезпечує стійкість системи, будь-які зміни в діяльності таких установ призводять до дисбалансу в роботі інших установ, що працюють на банківському ринку, а банкрутство системно важливих банків обов'язково призведе до поширення шоків на ринку та підриву фінансової безпеки всього сектору.

Таким чином, поняття «системно важливий банк» пов'язане із поняттям системного ризику (systemic risk). Сам термін «системний ризик» відносно новий: перша згадка в назві наукової роботи в галузі економіки та фінансів відбулася лише в 1994 р. [10, С.25]. Причому найчастіше це поняття використовується без однозначного визначення. Пояснюється це тим, що термін не $є$ результатом економічних досліджень, він запозичений менеджерами комерційних банків зі сфери політичних відносин. Зазвичай, під системним ризиком зазвичай розуміють ризик одночасного або послідовного банкрутства декількох фінансових установ, що призводить до настання фінансової кризи.

Зв'язок між системним ризиком та системно важливим банком розглядається вченими за двома підходами.

Відповідно до першого підходу до уваги береться системна подія та участь в ній конкретного системно важливого банку. При такому підході 
відбувається оцінка первісного системного ризику, що пов'язаний із виникненням шоку в банківській системі, та його подальше розподілення між учасниками ринку. В якості основних факторів, які зазвичай розглядаються як істотні, що впливають на системний ризик, виділяють: шоки ліквідності, проблеми ефективності, вплив обмінного курсу, валютні диспропорції національних економік, взаємопов'язаність фінансових інститутів у фінансовій системі та ін. [11, С.107-109]. Як зазначають Н. Шульга та С. Колодізєва «якщо втрати внаслідок реалізованого системного ризику будь-якої конкретної установи занадто великі порівняно із загальними втратами, то така установа буде розглядатися як системно важлива» [12, С.88].

Інший підхід пов'язаний із генерацією системного ризику системно важливими установами через вклад окремого банку в загальносистемний ризик.

Відомі західні фахівці в області банківських ризиків Д. Кауфман i К. Скотт визначають системний ризик як ризик або ймовірність збою всієї системи в зв'язку з виниклою недієздатністю ii окремих частин або компонентів [13]. Ю. Свлахова вважає, що системний ризик - це ризик, що властивий системі в цілому, як сукупності об'єктів і процесів, які називаються елементами, взаємопов'язаних і взаємодіючих між собою [14, С.37]. Тобто системні ризики виникають із взаємозв'язку елементів системи і поширюються на всю систему.

В якості причин виникнення системних ризиків Я. Міркін називає «ефект зараження» та «ефект доміно», що відбувається внаслідок концентрації та взаємозалежності фінансових установ [15]. Такі ефекти пов'язані із поширенням труднощів одного фінансового інституту, ринку чи системи на інші. Зокрема, вчені Г. Шелдон та М. Майєр розглядають банківську систему як мережу, пов'язану через міжбанківське кредитування і визначають ймовірність того, що банкрутство одного банку спричинить ланцюгову реакцію в інших банках, пов'язаних через міжбанківські кредити. Чим більша така вірогідність, тим більша системна важливість банку [16, С.5].

Ф. Х. Кіндт говорить про те, що системний ризик притаманний лише системно важливим фінансовим інститутам [17]. Таким чином, на думку вченого, тільки системно важливі банки $\epsilon$ генераторами системного ризику.

Цей підхід також покладено в основу визначення, що надає Національний банк України, відповідно до якого, системно важливий банк - це банк, банкрутство або неналежне функціонування якого може призвести до появи системних ризиків [26].

Виходячи 3 розглянутих положень, зазначимо, що сутність системно важливих банків доцільно розглядати через призму поняття «системний ризик», оскільки установа, що є носієм та джерелом системного ризику може вважатися системно важливою.

Отже, науковцями в основу поняття системно важливих банків закладено їх здатність генерувати системний ризик та можливість мати значний вплив на фінансову стабільність всього сектора. Проте, на наш погляд, цей підхід не $\epsilon$ достатнім для розкриття сутності 
системно важливих банків, оскільки не розкриває причин такого впливу.

3 огляду на це необхідним вбачається детальне розкриття основних характеристик системно важливих банків. У сучасній зарубіжній літературі зустрічаються різні тлумачення таких установ. Часто їх називають «занадто великими, щоб збанкрутувати» ("too big to fail", "too big to unwind", "too big to liquidate"), «занадто важливими, щоб збанкрутувати» ("too important to fail”), «занадто системними, щоб збанкрутувати» ("too systemic to fail") тощо відповідно до факторів їх системної важливості та причин надання їм державної підтримки.

В багатьох дослідженнях ключовою ознакою системно важливого банку вважають розмір його діяльності. Так, К. Джоу визначає системно важливий банк як такий фінансовий інститут, розмір якого, зазвичай, представлений обсягом його активів, і досягає таких розмірів, що він стає невід'ємною частиною функціонування фінансового ринку, його вихід із такого ринку може спричинити загальний крах [18]. Проте це визначення акцентує увагу лише на одному критерію, що характеризує величину банку, - розмірі активів, при цьому ігноруючи всі інші, такі як розмір капіталу, обсяг операцій тощо.

Часто під величиною діяльності системно важливих банків також розглядають таку ознаку, як ринкова вага. К. Джоу про поняття «too big to fail» також говорив, що це фінансовий інститут, який володіє значною долею ринку та має таку кількість економічних зв'язків, що його банкрутство матиме катастрофічні наслідки для світової економіки та/або для економіки окремої країни [18]. При цьому вчений 3осереджує увагу не тільки на розмірі установи, а зміщує акцент на долю ринку та взаємопов'язаність ('too interconnected to fail').

Деякі вчені серед інших ознак системно важливих банків виділяють системність («to systemic to fail») та важливість («too important to fail»).

На думку Е. Раджан, системність банку пов'язана із широкою диверсифікацією активів банку. Він зазначає, що банк можна назвати системно важливим, якщо його активи є диверсифікованими, тобто розподіленими на фінансовому ринку між великою кількістю інших установ, 3 метою мінімізації ризику [19]. Для зниження ризику шляхом диверсифікації банк такої категорії бере участь у великій кількості угод та інвестиційних проектів, таким чином провокуючи ефект «зараженНЯ».

На нашу думку, визначення ознак системності та важливості дублюють значення ознаки взаємопов'язаності, де в основі лежить твердження про можливість поширення ризику «зараження» системно важливими банками. Тому виділення окремо ознак системності та важливості вважаємо недоцільним.

Дж. Ротман зазначає, що ефект зараження справедливий також для невеликих банків, оскільки навіть невелика установа може викликати кризу, якщо вона має тісні фінансові зв'язки 3 іншими установами. На думку вченого, «якщо один 3 таких банків спотикається, наслідки поширюються в багатьох напрямках, а якщо багато 3 них спіткнуться одночасно, може ви- 
никнути криза» [20]. Таким чином, вчений розглядає системно важливі банки 3 позиції кількісної ознаки «занадто багато, щоб збанкрутувати» («too many to fail»).

Механізм характеристики «занадто багато, щоб збанкрутувати» паралельно розкривають у своїх працях $\mathrm{B}$. Ачарія [21], а також Т. Адріан та М. Бруннермаєр [22]. Так, на думку вчених, банки мають стимули для вибору співвідносних стратегій (як правило, під цим розуміють інвестування в активи з високим рівнем прибутковості). Це призводить до надмірного прийняття ризику щодо конкретних факторів, що створює негативні зовнішні ефекти і $є$ загрозою для стабільності фінансової системи. У певному сенсі, вибираючи подібні ризикові бізнесмоделі, банки створюють «ефект приналежності до натовпу» («systemic as part of a herd»), тим самим стають системно важливими.

Ряд вчених вказують на необхідність оцінки ступеня диверсифікації фінансової установи. Це твердження лежить в основі наступної ознаки системно важливих банків - ступеня складності («too complex to fail»), що може проявлятися у розрізі здійснюваних операцій (обсяг та складність операцій, масштаб надання послуг), взаємозв'язків 3 іншими учасниками (складність взаємопов'язаності), розгалуженої мережі філій (мережева складність) та інше. Як зазначає Б. Бернанке, фінансовий інститут, який має складну структуру власності, розподілену на фінансовому ринку між значною кількістю інших фінансових інститутів системи, який у випадку банкрутства/виходу з ринку може спрово- кувати негативні наслідки для системи та економіки, можна вважати системно важливим [23]. Таким чином, вчений робить акцент на складності структури власності банку, при цьому небезпека вбачається у створенні конфлікту інтересів між власниками такої установи.

Також розповсюдженим є використання ознаки складності заміни («too substitution to fail»). Як зазначає $\mathrm{H}$. Приказюк, ця ознака характеризує системно важливі фінансові інститути як такі, без яких функціонування фінансової системи значно ускладняється, а відновлення рівноваги системи є досить тривалим [24, С.25]. Взаємозамінність системно важливого банку визначається його унікальністю, що може проявлятися також набором послуг, що надає така установа, в результаті чого виявляється наскільки сильний є вплив банку на систему і чи може остання функціонувати у разі його банкрутства.

Розглядаючи сутність системно важливих банків необхідним є вивчення цього питання в комплексі. Тому до таких інститутів можуть бути віднесені установи, що мають значний вплив на інших учасників системи та на систему загалом (а іноді і на реальний сектор економіки), насамперед, через відношення до системного ризику, та відповідають хоча б одній ознаці системної важливості. На нашу думку, вдалим $\epsilon$ визначення С. Тозара та Б. Швандта, які під системно важливим фінансовим інститутом розуміють установу, яка через свій розмір, складність, взаємопов'язаність є джерелом підвищення системного ризику, що в свою чергу, уможливлює впливати на 
стан фінансової системи, а через неї, i на всю економіку [25, С.2].

На основі розглянутих підходів та власного бачення пропонуємо наступ- не узагальнення характерних ознак системної важливості банків (рис.1).

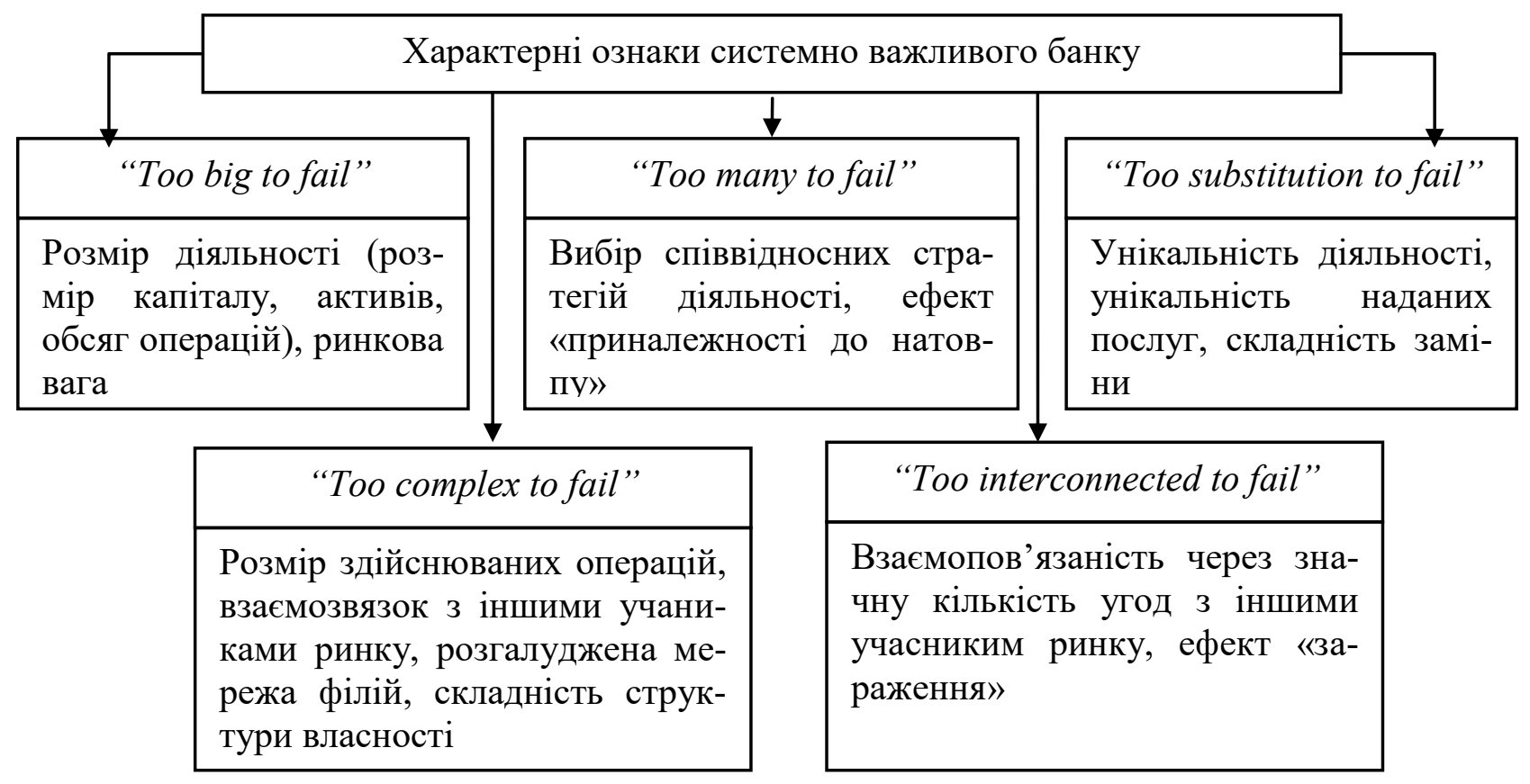

Рис.1. Характерні ознаки системно важливого банку

Джерело:складено автором на основі [18] - [25] та власних напрацюювань

В свою чергу, на підставі узагальнення та порівняння різних позицій щодо розуміння сутності системно важливого банку, ми пропонуємо власне визначення його поняття. Так, під системно важливим банком ми розглядаємо установу, для якої притаманний комплекс характеристик, що відповідають критеріям системної важливості, має здатність генерувати системний ризик, через що значно впливає на функціонування інших фінансових інститутів та в разі будь-яких структурних змін може спровокувати дестабілізацію всієї фінансової системи, а в деяких випадках, і реального сектору економіки.
Висновки. В статті було розглянуто сутність поняття «системно важливий банк», «системно значущий фінансовий інститут» та «системоутворюючий фінансовий інститут. Також проаналізовано характерні ознаки системно важливого банку, які можна класифікувати за наступними підходами: розмір, ринкова вага, ступінь складності, взаємопов'язаність, тощо.

Таким чином, різні підходи до трактування системно важливих банків вимагають упорядкування їх потянійного апарату, що, в свою чергу, дозволить підтримувати стабільність свієї банківської системи. 


\section{Список використаної літератури}

1. Таштамиров М. Р., Вараев А. А. Системно значимые банки: современное состояние и угроза системного риска. Ученые записки Крымского инженернопедагогического университета. 2018. №2(60). С.178-183.

2. Стегнієнко М.О. Особливості підходів до ідентифікації системно важливих банків. Фінансово-кредитна діяльність: проблеми теорії та практики. 2015. Вип. 2. С. 42-50. URL: http://nbuv.gov.ua/UJRN/Fkd_2015_2_8.

3. Лавренюк В. Системно важливі банки та їх вплив на стабільність банківської системи: дис..канд. екон. наук : 08.00.08 . КНТЕУ. Київ, 2016. 280 с.

4. Краснова I., Лавренюк В. Сутність та критерії ідентифікації системно важливих банків. Вісник Національного банку України. 2015. № 5. C. 18-24. URL: http://nbuv.gov.ua/UJRN/Vnbu_2015_5_9.

5. Кузнєцова Л. В. Вплив фінансової глобалізації, інтернаціоналізації та інтеграції на розвиток банківської системи України. Вісник Національного університету «Львівська політехніка». 2007. Вип. 606. С. 294-300.

6. Сучкова Е. О. Об идентификации системно значимых банков на национальном уровне. Деньги и кредит. №4. 2017. С. 54-61.

7. Weistroffer C. Identifying Systemically Important Financial Institutions (SIFIs). Deutsche Bank Research. 2011. №11. URL: https://econpapers.repec.org/paper/esswpaper/id_3a4383.htm.

8. Anwar Y. Managing Systemically Important Financial Institutions (SIFIs). The second meeting of the Financial Stability Board (FSB) Regional Consultative Group for Asia. Kuala Lumpur. 2012. URL: https://www.bis.org/review/r120615k.pdf.

9. Алешина А., Гургенидзе В. Системно значимые финансовые институты и их влияние на системный риск в банковской сфере. Общество и экономика. 2016. №9. C. 33-50.

10. Власенко М. Системный риск банковского сектора: подходы к анализу и оценке. Банкаускі веснік. 2012. № 4. C.12-16. URL: http://www.nbrb.by/bv/ articles/8931.pdf.

11. Манаев В. Измерение системного риска. Риск-менеджмент в кредитной организации. 2013. № 3. С. 105-110. URL: http://future banking.ru/reglamentbank /article/1428 
12. Шульга Н., Колодізєва С. Ідентифікація системно важливих банків. Вісник КНТЕУ. 2016. №5. С.82-98.

13. Kaufman, G., Scott, K. What is Systemic Risk, and do Bank Regulators Retard or Contribute to it?. URL: http://www.independent.org/pdf/tir/tir_07_3_scott.pdf

14. Евлахова Ю.С. Снижение системных рисков на финансовом рынке: новые подходы в регулировании. Финансы и кредит. 2010. № 16 (400). С. 35-40.

15. Миркин Я.М. Мониторинг системного риска в Российской Федерации на финансовых рынках. Аналитический доклад. 2011. URL: http://www.mirkin.ru/index.php?option=com_content\&view=category\&layout=blog $\& \mathrm{id}=124 \&$ Itemid $=247$

16. Sheldon G. \& Maurer M. Interbank lending and systemic risk: An empirical analysis for Switzerland. Swiss Journal of Economics and Statistics. URL: http://www.sjes.ch/papers/1998-IV-20.pdf

17. Xin H., Zhou H. \& Zhu H. A Framework for Assessing the Systemic Risk of Major Financial Institutions. Working Papers 281. April 2009. URL: http:// www.bis.org/publ/work281.htm.

18. Zhou C. Are Banks Too Big to Fail? Measuring Systemic Importance of Financial Institutions. International Journal of Central Banking. URL: https://www.ijcb.org/journal/ijcb10q4a10.pdf

19. Rajan E. \& Raghuram G. Too Systemic to Fail: Conserquences? Causes? And Potencial Remedies. Gleacher Distinguished Service Professor of Finance at the University of Chicago's Booth School of Business to the Senate Banking Committee Hearing. May $6^{\text {th }}$ 2009. URL: http://www.bis.org/events/conf090625/rajanpaper1.pdf 20. Rothman J. Too Connected to Fail. The Boston Globe. URL: http://archive.boston.com/bostonglobe/ideas/brainiac/2012/08/too_connected_t.html 21. Acharya V. \& Yorulmazer T. Too Many to Fail. Bank of England Working Paper. 2007. Vol. 16, Issue 1. URL: https://econpapers.repec.org/ article/eeejfinin/v_3a16_3ay_3a2007_3ai_3a1_3ap_3a1-31.htm.

22. Adrian T. \& Brunnermeier M. CoVaR. Federal Reserve Bank of New York Staff Reports. 2014. URL: https://www.newyorkfed.org/ medialibrary/media/research/staff_reports/sr348.pdf.

23. Bernanke B. Financial reform to address systemic risk. federalreserve.gov. URL: http://www.federalreserve.gov/newsevents/speech/ bernanke/20090310a.htm 
24. Приказюк Н. Компоративізм понять «системно важливі» та «системно утворюючі фінансові інститути». Вісник Київського національного університету імені Тараса Шевченка. 2017. №5 (194). С. 22-29.

25. Tosar S. \& Schwandt B. Has 'Too Big To Fail' Been Solved? Journal of Risk and Financial Management. 2019. Vol.12. pp. 1-14. URL: https://www.researchgate.net/publication/330813288_Has_'Too_Big_To_Fail'_Been_ Solved_A_Longitudinal_Analysis_of_Major_US_Banks.

26. Національний банк України: офіційний сайт. URL: https://www.bank.gov.ua/. 